\title{
THE APPLICATION OF ASYMMETRIC LIQUIDITY RISK MEASURE IN MODELLING THE RISK OF INVESTMENT
}

Przemysław Garsztka, Ph.D.

Poznań University of Economics

Faculty of Informatics and Electronic Economy

Department of Econometrics

al. Niepodległości 10, 61-875 Poznań, Poland

e-mail:przemyslaw.garsztka@ue.poznan.pl

Krzysztof Hołubowicz, Msc.

Poznań University of Economics

Faculty of Informatics and Electronic Economy

al. Niepodlegtości 10, 61-875 Poznań, Poland

e-mail:kholubowicz@gmail.com

Received 6 October 2014, Accepted 30 June 2015

\begin{abstract}
The article analyses the relationship between investment risk (as measured by the variance of returns or standard deviation of returns) and liquidity risk. The paper presents a method for calculating a new measure of liquidity risk, based on the characteristic line. In addition, it is checked what is the impact of liquidity risk to the volatility of daily returns. To describe this relationship dynamic econometric models were used. It was found that there was an econometric relationship between the proposed measure liquidity risk and the variance of returns.
\end{abstract}

Keywords: specific risk, assets liquidity, dynamic econometric model.

JEL classification: G12, G17. 


\section{Introduction}

Investing in securities is involved with the risk of not achieving target profitability in the future. Since the time of work Markowitz (1952) as a risk assessment of investments in shares assumed a standard deviation or variance of returns. In his work Markowitz (1952) argues that the downside risk measures are a good approach to assess the risk of the investment. Using this approach could be for the assessment investment risk taking into account only part of the volatility of returns. One of the most popular methods of downside risk measurement in the case of shares is still the use of semi-variance or semi-deviation (Wolski, 2013; Pla-Santamaria, Bravo, 2013). Another approach to assess the risk of investments was proposed by Sharpe (1970). In his work can be found sharing the risk of investments into two categories, systematic risk - related to the stock market and specific risk - related to a specific security. However this classification is insufficient. In most applications it can be found that sharing the risk of the investment into several categories, belong either to the systematic risk or to specific risk. A good example of this could the paper by Jacobs and Levy (2013) where in the utility function the risks associated with leverage were taken into account. That function includes the risks and costs of margin calls - which can force borrowers to liquidate securities at adverse prices due to illiquidity - losses exceeding the capital invested, and the possibility of bankruptcy. Another approach to include additional categories of risk could be the work of Garsztka (2012). In this work the author proposes to take into account the liquidity risk associated with trading stocks with low liquidity. This risk is considered as part of a specific risk. When an investor trades stocks with lower liquidity it should be expected that there will be higher transaction costs.

Liquidity is a broad and elusive concept that generally denotes the ability to trade large quantities quickly, at low cost, and without moving the price (Pastor, Stambaugh, 2003). Attempts to measure the liquidity in this sense have been undertaken among others by Amihud and Mendelson (1986), where illiquidity can be measured by the cost of the immediate execution. An investor willing to transact faces a trade-off: He/she may either wait to transact at a favourable price or insist on immediate execution at the current bid or ask price. The quoted ask (offer) price includes a premium for immediate buying, and the bid price similarly reflects a concession required for immediate sale. ${ }^{1}$

In this paper, the authors decided to test whether the increased liquidity risk within the meaning of Garsztka (2012) may be a symptom of increased specific risks. For this purpose there are proposed econometric models to clarify the relationship between liquidity risk and

\footnotetext{
1 Other works in which the problem of illiquidity was mentioned it were e.g. work Amihud (2002) or Avramov, Chordia and Goyal (2006).
} 
specific risk. In the first and second section a method for estimating new liquidity risk measures is presented. In the third section an econometric model is proposed which tested the relationship between investment risk and liquidity risk. The final part of the paper presents the results of the empirical research.

\section{Characteristic line of asset and liquidity risk}

Characteristic line of asset or market model is called the equation:

$$
R_{i}=\alpha_{i}+\beta_{i} R_{M}+\varepsilon_{i}
$$

where: $R_{i}$ - rate of return on security $i ; R_{M}$ - rate of return on the market portfolio (e.g. index); $\varepsilon_{i}$ - random variable explain "distortion" outside of the capital market; ${ }_{i}, \beta_{i}$ - coefficients.

For random variables, the following assumptions:

- $E\left(\varepsilon_{i}\right)=0$ for each $i$,

$-\operatorname{cov}\left(\varepsilon_{i}, \varepsilon_{j}\right)=0$ for $i \neq j$,

$-\operatorname{cov}\left(\varepsilon_{i}, R_{M}\right)=0$ for each $i$.

Estimation of the parameters of the characteristic line usually is done by the classical method of the least squares, which usually requires an additional assumption of the normal distribution of variables, in particular $\varepsilon_{i}$.

Suppose that the return on asset depends on the situation on the market:

1. In the case of neutral information the changes of asset price come from randomly occurring sales orders and a random component of the characteristic line is normally distributed.

2. In the case of positive information the share is attractive to buyers and they are willing to pay a premium in order to accelerate the asset purchase.

3 . In the case of negative information the share is less attractive and investors want to sell assets and they are willing to make some concession in order to accelerate the sale of the shares.

Additionally, suppose that: The less liquid the share - the more difficult to conclude a transaction, the premium/concession must be greater.

Thus, for non-ideal liquid assets: when the stock increases - rates of return are higher than we expect and when the stock decreases - rates of return are smaller. As a consequence we can observe the skewness of the series of the rate of return. In addition, at a given moment of time: 
in the case of positive information there is a greater probability of a positive "optimistic" departure from the characteristic line, in the case of negative information there is a greater probability of a "pessimistic" departure from the characteristic line. It is the reason for the appearance of skewness of the random component of the characteristic lines. In the article, this situation will be treated as a risk factor and is called liquidity risk.

In the case of occurring liquidity risk information it should be able to get through the random component of the market model. Therefore, the component can be divided into two independent elements:

$-u_{i}>0$, which is a random component of the right-side distribution, which further explains in the case of increases - positive deviations from the characteristic line, and in the case of decreases - explains the negative deviation from the characteristic line and explains a premium paid by buyers/concessions made by sellers.

$-v_{i}$ is a random component of the symmetric distribution, explains the impact of random factors that make up the rest of the specific risk.

It is assumed that $u_{i}$ and $v_{i}$ are independent - in the given moment of time some of the information creates a "conventional" random component and some of - the additional deviation from the characteristic line.

Characteristic line, taking into account the two random components has the form:

$$
R_{i}=\alpha_{i}+\beta_{i} R_{M}+\left(v_{i} \pm u_{i}\right)
$$

where: $E\left(v_{i}\right)=0, \operatorname{cov}\left(v_{i}, v_{j}\right)=0$ dla $i \neq j, \operatorname{cov}\left(v_{i}, R_{M}\right)=0, \operatorname{cov}\left(u_{i}, R_{M}\right)=0, \operatorname{cov}\left(v_{i}, u_{i}\right)=0$. In the case of increasing trend, both components are added (explaining the positive deviation from the characteristic line), in the case of falls $u_{i}$ is subtracted.

Using the independence of the $u_{i}$ and $v_{i}$ the investment risk measured by the variance of rates of return $R_{i}$ can be written as (under the above assumptions):

$$
\begin{aligned}
D^{2}\left(R_{i}\right) & =D^{2}\left(\alpha_{i}+\beta_{i} R_{M}\right)+D^{2}\left(v_{i}\right)+D^{2}\left(u_{i}\right)= \\
& =\beta_{i}^{2} D^{2}\left(R_{M}\right)+D^{2}\left(v_{i}\right)+D^{2}\left(u_{i}\right)
\end{aligned}
$$

where: $D^{2}\left(\alpha_{i}+\beta_{i} R_{M}\right)=D^{2}\left(\beta_{i} R_{M}\right)=\beta_{i}^{2} D^{2}\left(R_{M}\right)-$ it is systematic risk. 


\section{Estimate of the coefficients of a market model with liquidity risk}

In order to estimate the parameters of the model we used the approach proposed in the case of SFA models (Stochastic Frontier Analysis). In the paper of Battese and Corra (1977) is the proposition of parameterization for the distribution moments of random factors:

$$
D^{2}\left(R_{i}\right)=D^{2}\left(u_{i}\right)+D^{2}\left(v_{i}\right), \gamma_{i}=\frac{D^{2}\left(u_{i}\right)}{D^{2}\left(R_{i}\right)}
$$

where $u_{i}$ is cut, right-handed normal distribution $\left.u_{i} \sim N\left(0, D^{2}\left(u_{i}\right)\right)\right|_{u \geq 0}$, and $v_{i} \sim N\left(0, D^{2}\left(v_{i}\right)\right)$. For this parameterization it was possible to determine the logarithm of maximum likelihood functions, allowing a total estimation of the coefficients of the equation (2) and the moments of the data distribution by the formula (4) - see the appendix of Battese and Coelli (1992) or Battese and Coelli (1995) where we have a likelihood estimator of coefficients of the equation (3) and parameters given by formula (4). The parameterization (4) can be treated accordingly, as a specific risk and the assessment of liquidity risk.

The parameter $\gamma_{i} \in\langle 0,1\rangle$ is the liquidity risk associated with the asymmetry of the residuals of the characteristic line. Values closer to 1 indicate a higher value of the premium/concessions associated with entering into the transaction. The parameter value is the greater, higher is the participation of the variance of the asymmetric random component in the total variance of random components. This measure therefore indicates what kind of risk is associated with the incorrect assessment of the behaviour of the rate of return on the asset relative to the market portfolio.

\section{Symptomatic model with liquidity risk as a symptom of investment risk}

Accordance with the hypothesis substituted if the liquidity risk is a symptom of the increasing risk of the investment we should get a significant relationship between the respective measures of these variables. In order to assess whether the liquidity risk is a symptom of investment risk we used an econometric model. For each share:

$$
R i s k_{t}=\alpha+\sum_{l=1}^{L} \theta_{l} \times R i s k_{t-l}+\sum_{i=0}^{I} \beta_{i} \times l i q_{t-i}+\varepsilon
$$

where: Risk $k_{t}$ means the estimator of investment risk at the time $t$; liq $q_{t}$ is liquidity risk at the same time $t$. 
Investment risk is usually measured by the standard deviation of return $D\left(R_{i}\right)$. In this case we used $\gamma_{i}$ as a measure of liquidity risk. Another popular approach to the measurement of investment risk is to use the variance of returns $D^{2}\left(R_{i}\right)$. In that model we used $D^{2}\left(u_{i}\right)$ as a measure of liquidity risk. Additionally we estimated two models: in the first one we chose for a response variable the absolute value daily rate of return $\left|R_{i}\right|$, and as a measure of liquidity risk we used $\gamma_{i}$. In the last analysed model we chose for a response variable the square daily rate of return $R_{i}^{2}$ and liquidity risk was measured by $D^{2}\left(u_{i}\right)$. The last two models are an attempt to describe how liquidity risk is linked to changes in the daily rate of return. These models are designed to verify the thesis that the high liquidity risk is correlated with the high change in the rates of returns.

\section{Results of the empirical research}

The study covered 20 companies listed on The Warsaw Stock Exchange (10 included in the WIG20 index and 10 included in the WIG80), and excluding financial institutions. The study was based on the daily rates of return calculated and based on daily closing prices during the period from September 3rd, 2012 to September 3rd, 2013. The rates of return were computed as relative increases in the prices of stocks according to the formula:

$$
i t=\frac{N_{i, t \quad 1} \quad N_{i t}}{i t} \times 100 \%
$$

where: $R_{i t}$ is the rate of return on security $i$ at time $t ; N_{i t}$ is the listed value of the security $i$ at time $t$. For each security estimators of investment risk and measures of liquidity risk were computed using the 30-day sliding window using the formula (2)-(4). This gave the time series 218 values of investment risk and liquidity risk measures for each of the securities.

Time series values of $\gamma_{i}$ were stationary and auto correlated. (in the case of securities considered to be more liquid securities we used the index WIG20 as a market portfolio, in the case of other securities we used the index WIG as a market portfolio). Then, the data models were estimated in the form of formula (5). In these models we selected which best meets the assumptions of linear regression. The results of the estimates and some tests include Tables $1-4$. The models in the tables is the best of those that include measures of liquidity risk as explanatory (symptomatic) variables. 
In the cases of all estimated models presented in Tables $1-4$, the residuals did not show nor autocorrelation (the F-form suggested by Harvey (1990) was the diagnostic test) nor the ARCH effect: the Autoregressive Conditional Heteroscedasticity test was used (Engle, 1982). The error autocorrelation test is the Lagrange-multiplier test for $\mathrm{r}$-th order residual autocorrelation, distributed as $\chi^{2}(r)$ in large samples, under the null hypothesis that there is no autocorrelation (that is, that the errors are white noise). The ARCH (AutoRegressive Conditional Heteroscedasticity) test in the present form tests the hypothesis $\eta=0$ in the model:

$$
E\left[\varepsilon_{\mathrm{t}}^{2} \mid \varepsilon_{\mathrm{t}-1}, \ldots, \varepsilon_{\mathrm{t}-\mathrm{r}}\right]=\mathrm{c}_{0}+\sum_{i=1}^{r} \eta_{\mathrm{i}} \varepsilon_{\mathrm{t}-\mathrm{i}}{ }^{2}
$$

where: $\eta=\left(\eta_{1}, \ldots, \eta_{\mathrm{r}}\right)^{\prime}$. We have $\mathrm{TR}^{2}$ as the $\chi^{2}$ test from the regression of $\varepsilon_{\mathrm{t}}^{2}$ on a constant and $\varepsilon_{t-1}^{2}$ to $\varepsilon_{t-\mathrm{r}}^{2}$ (called the ARCH test) which is asymptotically distributed as $\chi^{2}(\mathrm{r})$ on H0: $\eta=0$.

Because in all the estimated models we did not find evidence to reject the null hypothesis, detailed statistics of these tests were not presented (they were all very similar). Differing results were obtained using other tests which are included in Tables 1-4 (see appendix).

The Durbin-Watson statistics had values between 1.18 and 2.14; therefore there was no risk of spurious regression. The critical value of the t-Student statistics, calculated to determine whether individual coefficients are significantly different from zero was 1.97 . To explain the autocorrelation of the dependent variable, it usually was enough to take account of the variable lagged by one (in three cases lagged by two). The order of the lags for an estimator of liquidity risk was usually zero or one (except one case).

The Heteroscedasticity test (called the Hetero test) is based on White (1980), and involves an auxiliary regression of $\varepsilon_{t}^{2}$ on the original regressors and all their squares. The null hypothesis is unconditional homoscedasticity.

In the case of shares from the WIG20 (containing the largest and most liquid companies on the WSE) liquidity risk as measured by $\gamma_{i}$ was usually an important explanatory variable for the conventional volatility - measured by the standard deviation of the rates of returns (see Table 1a). In 6 out of 10 models, we can confirm the relationship between the variables, and the models fit well the empirical data $\left(\mathrm{R}^{2}\right.$ of about 0.9 or greater).

In the case of less liquid stocks such a relationship could not be confirmed (see Table 1b). A suitable model was obtained only in the case of one company, which is KREZUS.

In the models for which the parameters were obtained that are significantly different from zero, the signs of the parameters $\beta_{0}$ are differ. It cannot therefore indicate clearly the nature of the relationship. Therefore it was difficult to deduce the kind of general relationship between 
the liquidity risk measured by $\gamma_{i}$, and the risk of investment measured by the standard deviation of returns.

In the case of models for the relationship between investment risk - measured by the variance of returns, and liquidity risk - measured by the variance of the random component $D^{2}\left(u_{i}\right)$, in most cases can be found a statistically significant relationship. In 15 cases out of 20 the examined companies (both from the WIG20 and the WIG80), received good econometric models (see Tables $2 \mathrm{a}$ and $2 \mathrm{~b}$ ). In the case of KGHM, the resulting model is too complex to be able to be considered useful. In two cases (PKOBP and COL) models could be considered useful at the significance level of $\alpha=0.1$. In all models, the sign of the parameter for the not lagged variable $D^{2}\left(u_{i}\right)$ namely $\beta_{0}$, and the sum of parameters $\Sigma \beta_{i}$ for independent variables are positive. This indicates a positive correlation between the variance of returns and the variance of the random component $u_{i}$. All models in table $2 \mathrm{a}$ and table $2 \mathrm{~b}$ with parameters significantly different from zero fit well into the empirical data ( $\mathrm{R}^{2}$ above 0.9$)$. It can therefore be regarded as an attempt to build such a model as success.

When the authors tried to examine the impact of the liquidity risk measured by $\gamma_{i}$ on changes of the daily returns measured by the absolute value of returns (Tables $3 a$ and $3 b$ ) attempts to find a good econometric model failed. Only in 5 cases out of 20 of the examined companies may it be noted that the parameters of the independent variables are significantly different from zero. Unfortunately, the signs of the parameter $\beta_{0}$ are different, which does not allow drawing conclusions about the relationship. In addition, no one model can be considered to fit the empirical data well. In two cases, on the basis of the RESET test it may be rejected by the hypothesis of linear dependence.

Table $4 \mathrm{a}$ and table $4 \mathrm{~b}$ contain the results of the estimation of econometric models describing the relationship between $R_{i}^{2}$ and variance of the random component $D^{2}\left(u_{i}\right)$. In almost half of the cases the described relationship is not a linear relationship, on the basis of the RESET test. Moreover, none of the estimated models cannot be considered to fit the empirical data well. But on the other hand, in 14 cases out of 20 examined companies the parameters $\beta_{i}$ are significantly different from zero. This points to a relationship between the study variables. Also, a sign of the parameter for the unlagged variable $D^{2}\left(u_{i}\right)$ namely $\beta_{0}$, and the sum of parameters $\Sigma \beta_{i}$ for independent variables are positive. This partly confirmed the thesis that the significant changes in the rate of return may be associated with the high risk of the liquidity measured by $D^{2}\left(u_{i}\right)$. 


\section{Conclusions}

The best results were obtained for the estimation of models in which the dependent variable was $D^{2}\left(R_{i}\right)$ and as a measure of liquidity risk $D^{2}\left(u_{i}\right)$ were used. In $80 \%$ of cases of the estimated models that fit well the empirical data and parameters of the independent variables are significantly different from zero. Thus, it can be said that this is an important symptomatic variable for investment risk as measured by $D^{2}\left(R_{i}\right)$. Since the sign of the parameter for the unlaggaed variable $D^{2}\left(u_{i}\right)$ i.e. $\beta_{0}$, and the sum of parameters $\Sigma \beta_{i}$ for independent variables are positive, we can indicate a positive correlation between the variance of returns and the variance of the random component $u_{i}$. In this sense, liquidity risk is a part of investment risk. But it is another kind of risk, and provides additional information.

In the case of shares from the WIG20 index, parameter $\gamma_{i}$ is important symptomatic variable for investment risk as measures by standard deviation $D\left(R_{i}\right)$. Unfortunately, this conclusion does not apply to less liquid shares. Similarly, for the models where the dependent variable was the absolute value of the rate of return, the authors failed to find an acceptable econometric model.

In the case of models describing the relationship between $R_{i}^{2}$ and variance of the random component $D^{2}\left(u_{i}\right), 70 \%$ of the model parameters of the independent variables are significantly different from zero. Also, a sign of the parameter $\beta_{0}$, and the sum of parameters $\Sigma \beta_{i}$ for independent variables are positive. Therefore, it can partially confirm the impact of liquidity risk to the volatility of daily returns. Unfortunately, this model does not fit well with the empirical data. Furthermore, in half of the cases the described relationship is not a linear relationship.

In conclusion, the parameter $\gamma_{i}$ is a measure of liquidity, which can be easily interpreted. However, the dependence on other selected investment risk measures did confirm (at least partially) for the variance of the random component $D^{2}\left(u_{i}\right)$. 


\section{Appendix}

Table 1a. The best symptomatic models for $D\left(R_{i}\right)$, and $\gamma_{i}$ as liquidity risk. Shares from WIG20

\begin{tabular}{|c|c|c|c|c|c|c|}
\hline Shares & \multicolumn{4}{|c|}{ Equation for dependent variable } & \multicolumn{2}{|c|}{ Summary: regression and tests for residuals } \\
\hline BRE & $\begin{array}{r}0.0002 \\
(0.774)\end{array}$ & $\begin{array}{l}+0.988 D\left(R_{t-1}\right) \\
\quad(85.6)\end{array}$ & $\begin{array}{l}+0.00094 \gamma_{t} \\
(2.79)\end{array}$ & $\begin{array}{l}-0.0001 \gamma_{t-1} \\
(-2.97)\end{array}$ & $\begin{array}{l}\mathrm{R}^{2}=0.973476 \\
\text { Normality test: } \\
\text { Hetero test: } \\
\text { RESET test: }\end{array}$ & $\begin{array}{l}\mathrm{DW}=1.53 \\
\mathrm{Chi}^{2}(2)=46.537[* *] \\
\mathrm{F}(6,206)=2.6373\left[^{*}\right] \\
\mathrm{F}(1,212)=0.0021443\end{array}$ \\
\hline PEKAO & $\begin{array}{l}0.00024 \\
(0.963)\end{array}$ & $\begin{array}{l}+0.98 D\left(R_{t-1}\right) \\
(65.3)\end{array}$ & $\begin{array}{r}+0.000 \\
(0.38\end{array}$ & $62 \gamma_{t}$ & $\begin{array}{l}\mathrm{R}^{2}=0.953316 \\
\text { Normality test: } \\
\text { Hetero test: } \\
\text { RESET test: }\end{array}$ & $\begin{array}{l}\mathrm{DW}=1.68 \\
\mathrm{Chi}^{2}(2)=1098.2[* *] \\
\mathrm{F}(4,208)=0.99516 \\
\mathrm{~F}(1,212)=0.0016590\end{array}$ \\
\hline HAWE & $\begin{array}{l}-0.00004 \\
(-0.769)\end{array}$ & $\begin{array}{l}+0.974 D\left(R_{t-1}\right) \\
\quad(71.0)\end{array}$ & $\begin{array}{c}+0.0036 \gamma_{t} \\
(3.18)\end{array}$ & $\begin{array}{l}-0.0026 \gamma_{t-1} \\
(-2.27)\end{array}$ & $\begin{array}{l}\mathrm{R}^{2}=0.964037 \\
\text { Normality test: } \\
\text { Hetero test: } \\
\text { RESET test: }\end{array}$ & $\begin{array}{l}\mathrm{DW}=1.68 \\
\mathrm{Chi}^{2}(2)=274.76[* *] \\
\mathrm{F}(6,204)=0.88579 \\
\mathrm{~F}(1,212)=0.054451\end{array}$ \\
\hline KGHM & $\begin{array}{l}-0.00007 \\
(-0.289)\end{array}$ & $\begin{array}{l}+0.996 D\left(R_{t-1}\right) \\
\quad(98.4)\end{array}$ & $\begin{array}{r}+0.00 \\
(1.1\end{array}$ & & $\begin{array}{l}\mathrm{R}^{2}=0.978413 \\
\text { Normality test: } \\
\text { Hetero test: } \\
\text { RESET test: }\end{array}$ & $\begin{array}{l}\mathrm{DW}=1.27 \\
\mathrm{Chi}^{2}(2)=211.64[* *] \\
\mathrm{F}(4,209)=3.4871[* *] \\
\mathrm{F}(1,212)=0.017741\end{array}$ \\
\hline LBW & $\begin{array}{l}-0.0019 \\
(-2.45)\end{array}$ & $\begin{array}{l}+0.982 D\left(R_{t-1}\right) \\
(106.0)\end{array}$ & $\begin{array}{r}+0.00 \\
(3.2\end{array}$ & & $\begin{array}{l}\mathrm{R}^{2}=0.98317 \\
\text { Normality test: } \\
\text { Hetero test: } \\
\text { RESET test: }\end{array}$ & $\begin{array}{l}\mathrm{DW}=1.99 \\
\mathrm{Chi}^{2}(2)=307.87[* *] \\
\mathrm{F}(4,208)=1.3317 \\
\mathrm{~F}(1,212)=0.022537\end{array}$ \\
\hline LPP & $\begin{array}{l}0.00096 \\
(2.36)\end{array}$ & $\begin{array}{l}+0.951 D\left(R_{t-1}\right) \\
\quad(45.1)\end{array}$ & $\begin{array}{c}-0.00134 \gamma_{t} \\
(-3.71)\end{array}$ & $\begin{array}{l}+0.0012 \gamma_{t-1} \\
(3.36)\end{array}$ & $\begin{array}{l}\mathrm{R}^{2}=0.906229 \\
\text { Normality test: } \\
\text { Hetero test: } \\
\text { RESET test: }\end{array}$ & $\begin{array}{l}\mathrm{DW}=1.82 \\
\mathrm{Chi}^{2}(2)=172.14[* *] \\
\mathrm{F}(6,204)=2.7625[*] \\
\mathrm{F}(1,212)=0.0040329\end{array}$ \\
\hline NETIA & $\begin{array}{l}-0.00015 \\
(-0.247)\end{array}$ & $\begin{array}{l}+0.964 D\left(R_{t-1}\right) \\
(62.0)\end{array}$ & $\begin{array}{r}+0.0 \\
(1.5\end{array}$ & & $\begin{array}{l}\mathrm{R}^{2}=0.953774 \\
\text { Normality test: } \\
\text { Hetero test: } \\
\text { RESET test: }\end{array}$ & $\begin{array}{l}\mathrm{DW}=2.1 \\
\mathrm{Chi}^{2}(2)=1177.4[* *] \\
\mathrm{F}(4,208)=0.78397 \\
\mathrm{~F}(1,212)=2.9822\end{array}$ \\
\hline PGNIG & $\begin{array}{l}0.000397 \\
(1.41)\end{array}$ & $\begin{array}{l}+0.972 D\left(R_{t-1}\right) \\
\quad(60.4)\end{array}$ & $\begin{array}{r}+0.0 \\
(0\end{array}$ & $\begin{array}{l}2174 \gamma_{t-1} \\
65)\end{array}$ & $\begin{array}{l}\mathrm{R}^{2}=0.952136 \\
\text { Normality test: } \\
\text { Hetero test: } \\
\text { RESET test: }\end{array}$ & $\begin{array}{l}\mathrm{DW}=1.93 \\
\mathrm{Chi}^{2}(2)=635.77[* *] \\
\mathrm{F}(4,208)=0.48804 \\
\mathrm{~F}(1,212)=0.15668\end{array}$ \\
\hline PKNORLEN & $\begin{array}{r}0.001 \\
(1.91)\end{array}$ & $\begin{array}{l}+0.956 D\left(R_{t-1}\right) \\
\quad(42.0)\end{array}$ & $\begin{array}{c}-0.0017 \gamma_{t} \\
(-3.11)\end{array}$ & $\begin{array}{l}+0.00157 \gamma_{t-1} \\
\quad(2.86)\end{array}$ & $\begin{array}{l}\mathrm{R}^{2}=0.895299 \\
\text { Normality test: } \\
\text { Hetero test: } \\
\text { RESET test: }\end{array}$ & $\begin{array}{l}\mathrm{DW}=1.91 \\
\mathrm{Chi}^{2}(2)=52.041[* *] \\
\mathrm{F}(6,204)=4.0373[* *] \\
\mathrm{F}(1,212)=1.0416\end{array}$ \\
\hline РКOBP & $\begin{array}{c}0.000019 \\
(0.149)\end{array}$ & $\begin{array}{l}+0.9915 D\left(R_{t-1}\right) \\
(105.0)\end{array}$ & & $019 \gamma_{t}$ & $\begin{array}{l}\mathrm{R}^{2}=0.98192 \\
\text { Normality test: } \\
\text { Hetero test: } \\
\text { RESET test: }\end{array}$ & $\begin{array}{l}\mathrm{DW}=2.06 \\
\mathrm{Chi}^{2}(2)=112.40[* *] \\
\mathrm{F}(4,208)=1.4935 \\
\mathrm{~F}(1,212)=0.041214\end{array}$ \\
\hline
\end{tabular}

In brackets the t-Student statistics.

$*$ indicates significance at $5 \%, * *$ at $1 \%$.

Source: authors' own calculations. 
Table $1 \mathrm{~b}$. The best symptomatic models for $D\left(R_{i}\right)$, and $\gamma_{i}$ as liquidity risk. Shares from WIG80

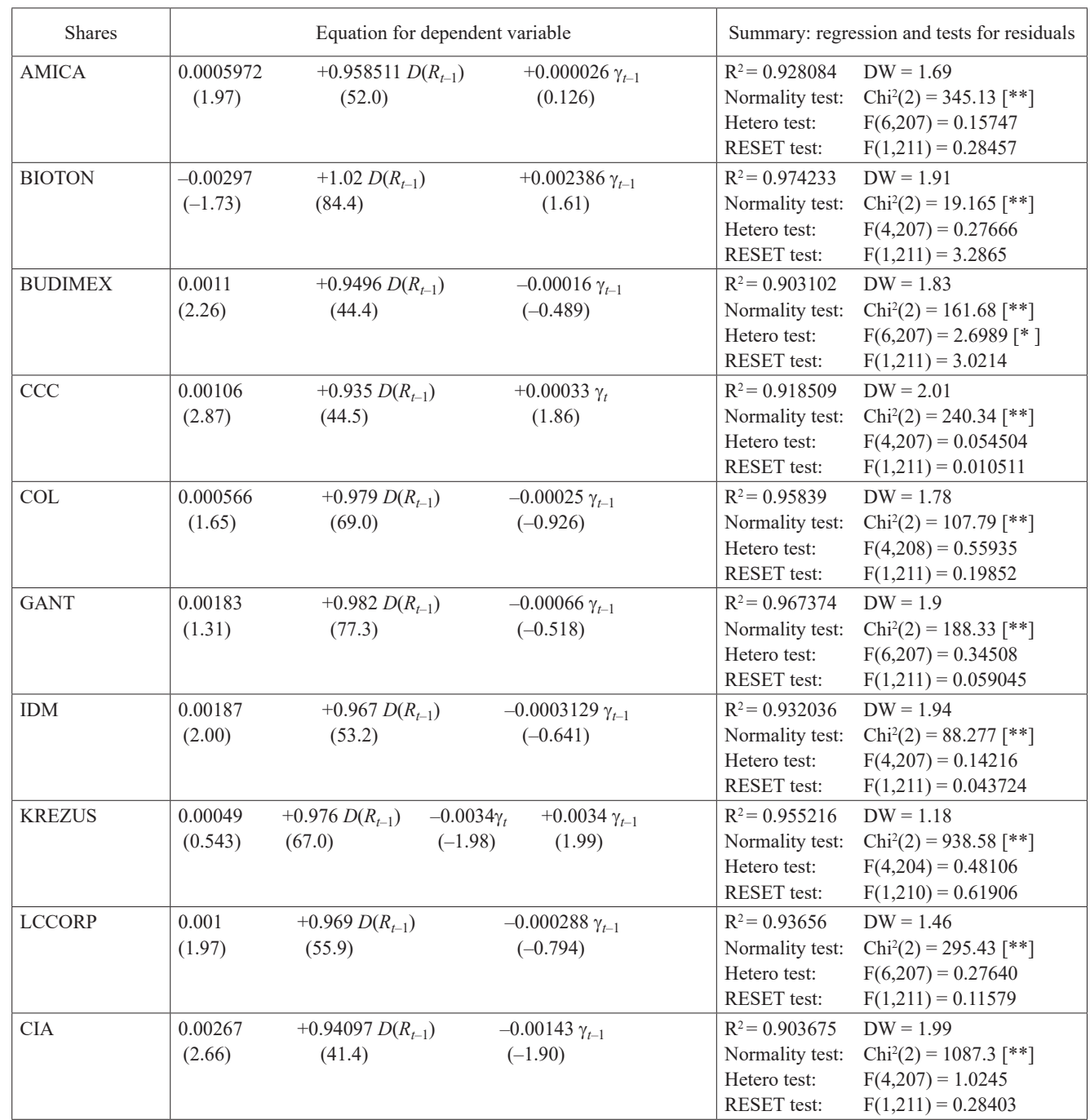

In brackets the t-Student statistics.

$*$ indicates significance at $5 \%, * *$ at $1 \%$.

Source: authors' own calculations. 
Table 2a. The best symptomatic models for $D^{2}\left(R_{i}\right)$, and $D^{2}\left(u_{i}\right)$ as liquidity risk. Shares from WIG20

\begin{tabular}{|c|c|c|c|c|c|c|}
\hline Shares & \multicolumn{4}{|c|}{ Equation for dependent variable } & \multicolumn{2}{|c|}{ Summary: regression and tests for residuals } \\
\hline BRE & $\begin{array}{c}-2.7 \mathrm{e}-007 \\
(-0.089)\end{array}$ & $\begin{array}{l}+0.98 D^{2}\left(R_{t-1}\right) \\
(82.9)\end{array}$ & $\begin{array}{l}+0.089 D^{2}\left(u_{t}\right) \\
(4.12)\end{array}$ & $\begin{array}{l}-0.065 D^{2}\left(u_{t-1}\right) \\
(-2.97)\end{array}$ & $\begin{array}{l}\mathrm{R}^{2}=0.976717 \\
\text { Normality test: } \\
\text { Hetero test: } \\
\text { RESET test: }\end{array}$ & $\begin{array}{l}\mathrm{DW}=1.51 \\
\mathrm{Chi}^{2}(2)=32.199\left[{ }^{* *}\right] \\
\mathrm{F}(6,206)=2.6346\left[{ }^{*}\right] \\
\mathrm{F}(1,212)=0.19978\end{array}$ \\
\hline PEKAO & $\begin{array}{c}3.2 \mathrm{e}-006 \\
(0.096)\end{array}$ & $\begin{array}{l}+0.98 D^{2}\left(R_{t-1}\right) \\
(62.8)\end{array}$ & $\begin{array}{l}+0.043 D^{2}\left(u_{t}\right) \\
(2.96)\end{array}$ & $\begin{array}{l}-0.037 D^{2}\left(u_{t-1}\right) \\
(-2.57)\end{array}$ & $\begin{array}{l}\mathrm{R}^{2}=0.954776 \\
\text { Normality test: } \\
\text { Hetero test: } \\
\text { RESET test: }\end{array}$ & $\begin{array}{l}\mathrm{DW}=1.73 \\
\mathrm{Chi}^{2}(2)=872.28[* *] \\
\mathrm{F}(6,206)=2.0261 \\
\mathrm{~F}(1,212)=0.40464\end{array}$ \\
\hline HAWE & $\begin{array}{c}1.5 \mathrm{e}-005 \\
(1.26)\end{array}$ & $\begin{array}{l}+0.916 D^{2}\left(R_{t-1}\right) \\
\quad(43.0)\end{array}$ & $\begin{array}{l}+0.135 D^{2}\left(u_{t}\right) \\
(6.76)\end{array}$ & $\begin{array}{l}-0.084 D^{2}\left(u_{t-1}\right) \\
(-3.96)\end{array}$ & $\begin{array}{l}\mathrm{R}^{2}=0.968716 \\
\text { Normality test: } \\
\text { Hetero test: } \\
\text { RESET test: }\end{array}$ & $\begin{array}{l}\mathrm{DW}=1.8 \\
\mathrm{Chi}^{2}(2)=247.02[* *] \\
\mathrm{F}(6,206)=3.3435[* *] \\
\mathrm{F}(1,212)=0.57824\end{array}$ \\
\hline KGHM & $\begin{array}{l}7.11 \mathrm{e}-007 \\
(1376) \\
-0.0373 D \\
(-2.12)\end{array}$ & $\begin{array}{l}+1.424 D^{2}( \\
(22.9) \\
+0.0597 \\
\quad(2.69)\end{array}$ & $\begin{array}{l}\left.R_{t-1}\right) \\
\left(u_{t-2}\right)\end{array}$ & $\begin{array}{l}0.433 D^{2}\left(R_{t-2}\right) \\
6.89) \\
0.0316 D^{2}\left(u_{t-3}\right) \\
(-1.8)\end{array}$ & $\begin{array}{l}\mathrm{R}^{2}=0.98314 \\
\text { Normality test: } \\
\text { Hetero test: } \\
\text { RESET test: }\end{array}$ & $\begin{array}{l}\mathrm{DW}=1.9 \\
\mathrm{Chi}^{2}(2)=101.38[* *] \\
\mathrm{F}(10,198)=4.0867[* *] \\
\mathrm{F}(1,212)=0.056252\end{array}$ \\
\hline LBW & $\begin{array}{l}1.4 \mathrm{e}-005 \\
(0.798)\end{array}$ & $\begin{array}{l}+0.866 D^{2}\left(R_{t-1}\right) \\
(36.8)\end{array}$ & $\begin{array}{l}+0.187 D^{2}\left(u_{t}\right) \\
(7.59)\end{array}$ & $\begin{array}{l}-0.103 D^{2}\left(u_{t-1}\right) \\
(-3.68)\end{array}$ & $\begin{array}{l}\mathrm{R}^{2}=0.983462 \\
\text { Normality test: } \\
\text { Hetero test: } \\
\text { RESET test: }\end{array}$ & $\begin{array}{l}\mathrm{DW}=2.21 \\
\mathrm{Chi}^{2}(2)=233.85[* *] \\
\mathrm{F}(6,206)=4.6073[* *] \\
\mathrm{F}(1,212)=0.000011\end{array}$ \\
\hline LPP & $\begin{array}{c}1.6 \mathrm{e}-005 \\
(2.13)\end{array}$ & $\begin{array}{c}+0.934 D^{2} \\
(40.7)\end{array}$ & & $\begin{array}{l}-0.017 D^{2}\left(u_{t-1}\right) \\
(1.44)\end{array}$ & $\begin{array}{l}\mathrm{R}^{2}=0.901449 \\
\text { Normality test: } \\
\text { Hetero test: } \\
\text { RESET test: }\end{array}$ & $\begin{array}{l}\mathrm{DW}=1.7 \\
\mathrm{Chi}^{2}(2)=167.19[* *] \\
\mathrm{F}(4,208)=0.92101 \\
\mathrm{~F}(1,212)=0.71734\end{array}$ \\
\hline NETIA & $\begin{array}{c}4.4 \mathrm{e}-005 \\
(4.79)\end{array}$ & $\begin{array}{c}+0.5047 \mathrm{D} \\
(13.4)\end{array}$ & $\left(R_{t-1}\right)$ & $\begin{array}{l}-0.2389 D^{2}\left(u_{t}\right) \\
(13.0)\end{array}$ & $\begin{array}{l}\mathrm{R}^{2}=0.966392 \\
\text { Normality test: } \\
\text { Hetero test: } \\
\text { RESET test: }\end{array}$ & $\begin{array}{l}\mathrm{DW}=1.87 \\
\mathrm{Chi}^{2}(2)=548.26\left[{ }^{* *}\right] \\
\mathrm{F}(4,208)=2.9252\left[{ }^{*}\right] \\
\mathrm{F}(1,212)=14.309\left[{ }^{* *}\right]\end{array}$ \\
\hline PGNIG & $\begin{array}{l}8.8 \mathrm{e}-006 \\
(1.68)\end{array}$ & $\begin{array}{l}+0.943 D^{2}\left(R_{t-1}\right) \\
(44.0)\end{array}$ & $\begin{array}{l}+0.065 D^{2}\left(u_{t}\right) \\
(3.87)\end{array}$ & $\begin{array}{l}-0.037 D^{2}\left(u_{t-1}\right) \\
(-2.16)\end{array}$ & $\begin{array}{l}\mathrm{R}^{2}=0.952998 \\
\text { Normality test: } \\
\text { Hetero test: } \\
\text { RESET test: }\end{array}$ & $\begin{array}{l}\mathrm{DW}=2.03 \\
\mathrm{Chi}^{2}(2)=551.52[* *] \\
\mathrm{F}(6,206)=5.8505[* *] \\
\mathrm{F}(1,212)=0.24027\end{array}$ \\
\hline PKNORLEN & $\begin{array}{c}1.5 \mathrm{e}-005 \\
(1.47)\end{array}$ & $\begin{array}{c}+0.955 \mathrm{D} \\
(41.1)\end{array}$ & $\left(R_{t-1}\right)$ & $\begin{array}{l}-0.0149 D^{2}\left(u_{t}\right) \\
(1.37)\end{array}$ & $\begin{array}{l}\mathrm{R}^{2}=0.887977 \\
\text { Normality test: } \\
\text { Hetero test: } \\
\text { RESET test: }\end{array}$ & $\begin{array}{l}\mathrm{DW}=1.91 \\
\mathrm{Chi}^{2}(2)=105.45[* *] \\
\mathrm{F}(4,208)=0.29870 \\
\mathrm{~F}(1,212)=1.1781\end{array}$ \\
\hline PKOBP & $\begin{array}{c}2.2 \mathrm{e}-006 \\
(1.14)\end{array}$ & $\begin{array}{r}+0.9787 \\
(76.7)\end{array}$ & $D^{2}\left(R_{t-1}\right)$ & $\begin{array}{l}+0.014977 D^{2}\left(u_{t-1}\right) \\
\quad(1.89)\end{array}$ & $\begin{array}{l}\mathrm{R}^{2}=0.97944 \\
\text { Normality test: } \\
\text { Hetero test: } \\
\text { RESET test: }\end{array}$ & $\begin{array}{l}\mathrm{DW}=2.06 \\
\mathrm{Chi}^{2}(2)=122.90[* *] \\
\mathrm{F}(6,206)=2.5883\left[{ }^{*}\right] \\
\mathrm{F}(1,212)=1.5851\end{array}$ \\
\hline
\end{tabular}

In brackets the t-Student statistics.

$*$ indicates significance at $5 \%, * *$ at $1 \%$.

Source: authors' own calculations. 
Table $2 \mathrm{~b}$. The best symptomatic models for $D^{2}\left(R_{i}\right)$, and $D^{2}\left(u_{i}\right)$ as liquidity risk. Shares from WIG80

\begin{tabular}{|c|c|c|c|c|c|c|}
\hline Shares & \multicolumn{4}{|c|}{ Equation for dependent variable } & \multicolumn{2}{|c|}{ Summary: regression and tests for residuals } \\
\hline AMICA & $\begin{array}{c}7.9 \mathrm{e}-006 \\
(1.99)\end{array}$ & $\begin{array}{l}+0.929 D^{2}\left(R_{t-1}\right) \\
\quad(41.0)\end{array}$ & $\begin{array}{l}+0.098 D^{2}\left(u_{t}\right) \\
(4.54)\end{array}$ & $\begin{array}{l}-0.07 D^{2}\left(u_{t-1}\right) \\
(-3.28)\end{array}$ & $\begin{array}{l}\mathrm{R}^{2}=0.937693 \\
\text { Normality test: } \\
\text { Hetero test: } \\
\text { RESET test: }\end{array}$ & $\begin{array}{l}\mathrm{DW}=1.79 \\
\mathrm{Chi}^{2}(2)=222.02[* *] \\
\mathrm{F}(6,206)=2.6670[*] \\
\mathrm{F}(1,212)=0.032680\end{array}$ \\
\hline BIOTON & $\begin{array}{l}-0.00037 \\
(-2.78)\end{array}$ & \multicolumn{2}{|c|}{$\begin{array}{l}+1.01875 D^{2}\left(R_{t-1}\right) \\
\quad(85.2)\end{array}$} & $\begin{array}{l}+0.0365 D^{2}\left(u_{t-1}\right) \\
(2.97)\end{array}$ & $\begin{array}{l}\mathrm{R}^{2}=0.98029 \\
\text { Normality test: } \\
\text { Hetero test: } \\
\text { RESET test: }\end{array}$ & $\begin{array}{l}\mathrm{DW}=1.98 \\
\mathrm{Chi}^{2}(2)=7.7696[* *] \\
\mathrm{F}(4,208)=5.2670[* *] \\
\mathrm{F}(1,212)=3.1347\end{array}$ \\
\hline BUDIMEX & $\begin{array}{l}1.8 \mathrm{e}-005 \\
(1.98)\end{array}$ & $\begin{array}{l}+0.94 D^{2}\left(R_{t-1}\right) \\
(39.3)\end{array}$ & $\begin{array}{l}+0.096 D^{2}\left(u_{t}\right) \\
(4.89)\end{array}$ & $\begin{array}{l}-0.081 D^{2}\left(u_{t-1}\right) \\
(-4.10)\end{array}$ & $\begin{array}{l}\mathrm{R}^{2}=0.906377 \\
\text { Normality test: } \\
\text { Hetero test: } \\
\text { RESET test: }\end{array}$ & $\begin{array}{l}\mathrm{DW}=1.93 \\
\mathrm{Chi}^{2}(2)=254.81[* *] \\
\mathrm{F}(6,206)=33.006[* *] \\
\mathrm{F}(1,212)=2.9566\end{array}$ \\
\hline $\mathrm{CCC}$ & $\begin{array}{c}2.9 \mathrm{e}-005 \\
(3.83)\end{array}$ & \multicolumn{2}{|c|}{$\begin{array}{l}+0.8896 D^{2}\left(R_{t-1}\right) \\
\quad(36.1)\end{array}$} & $\begin{array}{l}+0.0261 D^{2}\left(u_{t}\right) \\
\quad(3.98)\end{array}$ & $\begin{array}{l}\mathrm{R}^{2}=0.920274 \\
\text { Normality test: } \\
\text { Hetero test: } \\
\text { RESET test: }\end{array}$ & $\begin{array}{l}\mathrm{DW}=1.99 \\
\mathrm{Chi}^{2}(2)=282.41[* *] \\
\mathrm{F}(4,208)=0.41987 \\
\mathrm{~F}(1,212)=0.52503\end{array}$ \\
\hline $\mathrm{COL}$ & $\begin{array}{l}7.6 \mathrm{e}-006 \\
(1.26)\end{array}$ & \multicolumn{2}{|c|}{$\begin{array}{l}+0.97 D^{2}\left(R_{t-1}\right) \\
(59.1)\end{array}$} & $\begin{array}{l}+0.0178 D^{2}\left(u_{t}\right) \\
\quad(1.74)\end{array}$ & $\begin{array}{l}\mathrm{R}^{2}=0.95438 \\
\text { Normality test: } \\
\text { Hetero test: } \\
\text { RESET test: }\end{array}$ & $\begin{array}{l}\mathrm{DW}=1.76 \\
\mathrm{Chi}^{2}(2)=156.24[* *] \\
\mathrm{F}(4,208)=0.86914 \\
\mathrm{~F}(1,212)=0.84438\end{array}$ \\
\hline GANT & $\begin{array}{c}-1.4 \mathrm{e}-005 \\
(-0.215)\end{array}$ & \multicolumn{2}{|c|}{$\begin{array}{l}+0.953 D^{2}\left(R_{t-1}\right) \\
\quad(68.4)\end{array}$} & $\begin{array}{l}+0.0428 D^{2}\left(u_{t}\right) \\
\quad(4.05)\end{array}$ & $\begin{array}{l}\mathrm{R}^{2}=0.971594 \\
\text { Normality test: } \\
\text { Hetero test: } \\
\text { RESET test: }\end{array}$ & $\begin{array}{l}\mathrm{DW}=1.85 \\
\mathrm{Chi}^{2}(2)=169.29[* *] \\
\mathrm{F}(4,208)=0.84018 \\
\mathrm{~F}(1,212)=1.0214\end{array}$ \\
\hline IDM & $\begin{array}{r}0.0001 \\
(2.07)\end{array}$ & \multicolumn{2}{|c|}{$\begin{array}{l}+0.9529 D^{2}\left(R_{t-1}\right) \\
\quad(43.4)\end{array}$} & $\begin{array}{l}+0.0058895 D^{2}\left(u_{t}\right) \\
\quad(9.979)\end{array}$ & $\begin{array}{l}\mathrm{R}^{2}=0.932606 \\
\text { Normality test: } \\
\text { Hetero test: } \\
\text { RESET test: }\end{array}$ & $\begin{array}{l}\mathrm{DW}=1.85 \\
\mathrm{Chi}^{2}(2)=90.371[* *] \\
\mathrm{F}(4,208)=0.20831 \\
\mathrm{~F}(1,212)=0.34583\end{array}$ \\
\hline KREZUS & $\begin{array}{c}-1.8 \mathrm{e}-005 \\
(-1.71)\end{array}$ & $\begin{array}{l}+0.97 D^{2}\left(R_{t-1}\right) \\
(14.9)\end{array}$ & $\begin{array}{l}-0.289 D^{2}\left(R_{t-2}\right) \\
(-5.47)\end{array}$ & $\begin{array}{l}+0.293 D^{2}\left(u_{t}\right) \\
(10.0)\end{array}$ & $\begin{array}{l}\mathrm{R}^{2}=0.974105 \\
\text { Normality test: } \\
\text { Hetero test: } \\
\text { RESET test: }\end{array}$ & $\begin{array}{l}\mathrm{DW}=2.07 \\
\mathrm{Chi}^{2}(2)=191.03\left[{ }^{* *}\right] \\
\left.\mathrm{F}(6,205)=4.0369{ }^{* *}\right] \\
\mathrm{F}(1,211)=15.832[* *]\end{array}$ \\
\hline LCCORP & $\begin{array}{l}2.6 \mathrm{e}-005 \\
(2.0)\end{array}$ & $\begin{array}{l}+1.23 D^{2}\left(R_{t-1}\right) \\
(18.4)\end{array}$ & $\begin{array}{l}-0.29 D^{2}\left(R_{t-2}\right) \\
(-4.54)\end{array}$ & $\begin{array}{l}+0.0178 D^{2}\left(u_{t}\right) \\
\quad(2.11)\end{array}$ & $\begin{array}{l}\mathrm{R}^{2}=0.944865 \\
\text { Normality test: } \\
\text { Hetero test: } \\
\text { RESET test: }\end{array}$ & $\begin{array}{l}\mathrm{DW}=1.95 \\
\mathrm{Chi}^{2}(2)=291.74[* *] \\
\mathrm{F}(6,205)=0.44305 \\
\mathrm{~F}(1,211)=0.0050252\end{array}$ \\
\hline CIA & $\begin{array}{c}1.7 \mathrm{e}-005 \\
(1.10)\end{array}$ & $\begin{array}{l}+0.939 D^{2}\left(R_{t-1}\right) \\
(37.9)\end{array}$ & $\begin{array}{l}+0.127 D^{2}\left(u_{t}\right) \\
\quad(5.01)\end{array}$ & $\begin{array}{l}-0.109 D^{2}\left(u_{t-1}\right) \\
(-4.23)\end{array}$ & $\begin{array}{l}\mathrm{R}^{2}=0.915455 \\
\text { Normality test: } \\
\text { Hetero test: } \\
\text { RESET test: }\end{array}$ & $\begin{array}{l}\mathrm{DW}=2.14 \\
\mathrm{Chi}^{2}(2)=923.77[* *] \\
\mathrm{F}(6,206)=0.86784 \\
\mathrm{~F}(1,212)=0.0032247\end{array}$ \\
\hline
\end{tabular}

In brackets the t-Student statistics.

$*$ indicates significance at $5 \%, * *$ at $1 \%$.

Source: authors' own calculations. 
Table 3a. The best symptomatic models for $\left|R_{i}\right|$, and $\gamma_{i}$ as liquidity risk. Shares from WIG20

\begin{tabular}{|c|c|c|c|c|c|}
\hline Shares & \multicolumn{3}{|c|}{ Equation for dependent variable } & \multicolumn{2}{|c|}{ Summary: regression and tests for residuals } \\
\hline BRE & $\begin{array}{c}0.017 \\
(5.60)\end{array}$ & $\begin{array}{l}-0.008 \gamma_{t} \\
(-2.03)\end{array}$ & & $\begin{array}{l}\mathrm{R}^{2}=0.0188 \\
\text { Normality test: } \\
\text { Hetero test: } \\
\text { RESET test: }\end{array}$ & $\begin{array}{l}\mathrm{DW}=1.43 \\
\mathrm{Chi}^{2}(2)=112.41[* *] \\
\mathrm{F}(2,212)=0.44586 \\
\mathrm{~F}(1,213)=0.4147\end{array}$ \\
\hline PEKAO & $\begin{array}{l}0.007 \\
(4.60)\end{array}$ & $\begin{array}{l}+0.221\left|R_{t-1}\right| \\
(3.35)\end{array}$ & $\begin{array}{l}+0.001 \gamma_{t} \\
(0.558)\end{array}$ & $\begin{array}{l}\mathrm{R}^{2}=0.05199 \\
\text { Normality test: } \\
\text { Hetero test: } \\
\text { RESET test: }\end{array}$ & $\begin{array}{l}\mathrm{DW}=1.99 \\
\mathrm{Chi}^{2}(2)=71.285[* *] \\
\mathrm{F}(4,208)=0.3992 \\
\mathrm{~F}(1,212)=0.026716\end{array}$ \\
\hline HAWE & $\begin{array}{l}0.009 \\
(1.42)\end{array}$ & $\begin{array}{l}+0.178\left|R_{t-1}\right| \\
(2.65)\end{array}$ & $\begin{array}{l}+0.011 \gamma_{t} \\
(1.35)\end{array}$ & $\begin{array}{l}\mathrm{R}^{2}=0.04423 \\
\text { Normality test: } \\
\text { Hetero test: } \\
\text { RESET test: }\end{array}$ & $\begin{array}{l}\mathrm{DW}=2.01 \\
\mathrm{Chi}^{2}(2)=171.31[* *] \\
\mathrm{F}(4,208)=0.60785 \\
\mathrm{~F}(1,212)=0.75603\end{array}$ \\
\hline $\begin{array}{ll}\text { KGHM } & \text { (a) } \\
& \\
& \text { (b) }\end{array}$ & \begin{tabular}{|l}
0.0127 \\
$(4.35)$ \\
\\
0.0171 \\
$(5.9)$
\end{tabular} & $\begin{array}{l}+0.297\left|R_{t-1}\right| \\
(4.62) \\
\\
-0.0019 \gamma_{t} \\
(-0.715)\end{array}$ & $\begin{array}{l}-0.0029 \gamma_{t} \\
(-0.811)\end{array}$ & $\begin{array}{l}\mathrm{R}^{2}=0.09326 \\
\text { Normality test: } \\
\text { Hetero test: } \\
\text { RESET test: } \\
\mathrm{R}^{2}=0.002381 \\
\text { Normality test: } \\
\text { Hetero test: } \\
\text { RESET test: }\end{array}$ & $\begin{array}{l}\mathrm{DW}=1.96 \\
\mathrm{Chi}^{2}(2)=59.62[* *] \\
\mathrm{F}(4,208)=10.466[* *] \\
\mathrm{F}(1,212)=8.6250[* *] \\
\mathrm{DW}=1.36 \\
\mathrm{Chi}^{2}(2)=137.11[* *] \\
\mathrm{F}(2,212)=3.0364 \\
\mathrm{~F}(1,213)=0.51558\end{array}$ \\
\hline LBW & $\begin{array}{l}-0.006 \\
(-0.594)\end{array}$ & $\begin{array}{l}+0.179\left|R_{t-1}\right| \\
\quad(2.66)\end{array}$ & $\begin{array}{c}+0.03323 \gamma_{t} \\
(2.45)\end{array}$ & $\begin{array}{l}\mathrm{R}^{2}=0.07102 \\
\text { Normality test: } \\
\text { Hetero test: } \\
\text { RESET test: }\end{array}$ & $\begin{array}{l}\mathrm{DW}=2 \\
\mathrm{Chi}^{2}(2)=436.51[* *] \\
\mathrm{F}(4,208)=2.1478 \\
\mathrm{~F}(1,214)=0.23596\end{array}$ \\
\hline LPP & $\begin{array}{l}0.1069 \\
(4.26)\end{array}$ & $\begin{array}{l}+0.00442 \gamma_{t-1} \\
\quad(1.21)\end{array}$ & & $\begin{array}{l}\mathrm{R}^{2}=0.00677 \\
\text { Normality test: } \\
\text { Hetero test: } \\
\text { RESET test: }\end{array}$ & $\begin{array}{l}\mathrm{DW}=1.87 \\
\mathrm{Chi}^{2}(2)=99.928[* *] \\
\mathrm{F}(2,210)=1.8204 \\
\mathrm{~F}(1,212)=0.80906\end{array}$ \\
\hline NETIA & $\begin{array}{l}0.0055 \\
(1.01)\end{array}$ & $\begin{array}{l}+0.0105 \gamma_{t-1} \\
\quad(1.6)\end{array}$ & & $\begin{array}{l}\mathrm{R}^{2}=0.0118 \\
\text { Normality test: } \\
\text { Hetero test: } \\
\text { RESET test: }\end{array}$ & $\begin{array}{l}\mathrm{DW}=2.03 \\
\mathrm{Chi}^{2}(2)=873.51[* *] \\
\mathrm{F}(2,210)=0.52395 \\
\mathrm{~F}(1,212)=0.43075\end{array}$ \\
\hline PGNIG & $\begin{array}{l}0.0149 \\
(5.67)\end{array}$ & $\begin{array}{l}+0.0753\left|R_{t-1}\right| \\
\quad(1.1)\end{array}$ & $\begin{array}{l}-0.00329 \gamma_{t-1} \\
(-1.02)\end{array}$ & $\begin{array}{l}\mathrm{R}^{2}=0.010269 \\
\text { Normality test: } \\
\text { Hetero test: } \\
\text { RESET test: }\end{array}$ & $\begin{array}{l}\mathrm{DW}=2.01 \\
\mathrm{Chi}^{2}(2)=143.59[* *] \\
\mathrm{F}(4,208)=0.47614 \\
\mathrm{~F}(1,212)=0.26462\end{array}$ \\
\hline PKNORLEN & $\begin{array}{l}0.0184 \\
(5.46)\end{array}$ & $\begin{array}{l}-0.00471 \gamma_{t-1} \\
(-1.03)\end{array}$ & & $\begin{array}{l}\mathrm{R}^{2}=0.00497 \\
\text { Normality test: } \\
\text { Hetero test: } \\
\text { RESET test: }\end{array}$ & $\begin{array}{l}\mathrm{DW}=1.9 \\
\mathrm{Chi}^{2}(2)=118.44[* *] \\
\mathrm{F}(2,210)=0.82852 \\
\mathrm{~F}(1,212)=0.16779\end{array}$ \\
\hline PKOBP & $\begin{array}{l}0.0093 \\
(7.96)\end{array}$ & $\begin{array}{l}0.00493 \gamma_{t} \\
(2.16)\end{array}$ & $\begin{array}{c}-0.00367 \gamma_{t-1} \\
(-1.61)\end{array}$ & $\begin{array}{l}\mathrm{R}^{2}=0.02163 \\
\text { Normality test: } \\
\text { Hetero test: } \\
\text { RESET test: }\end{array}$ & $\begin{array}{l}\mathrm{DW}=1.97 \\
\mathrm{Chi}^{2}(2)=54.794\left[{ }^{* *}\right] \\
\mathrm{F}(4,208)=2.4222\left[{ }^{*}\right] \\
\mathrm{F}(1,212)=0.16779\end{array}$ \\
\hline
\end{tabular}

In brackets the t-Student statistics.

$*$ indicates significance at $5 \%, * *$ at $1 \%$.

Source: authors' own calculations. 
Table $3 \mathrm{~b}$. The best symptomatic models for $\left|R_{i}\right|$, and $\gamma_{i}$ as liquidity risk. Shares from WIG80

\begin{tabular}{|c|c|c|c|c|c|c|}
\hline Shares & \multicolumn{4}{|c|}{ Equation for dependent variable } & \multicolumn{2}{|c|}{ Summary: regression and tests for residuals } \\
\hline AMICA & $\begin{array}{r}0.0107 \\
(3.84)\end{array}$ & $\begin{array}{l}+0.1772\left|R_{t-1}\right| \\
(2.63)\end{array}$ & $\begin{array}{l}-0.0024 \\
(-0.718)\end{array}$ & & $\begin{array}{l}\mathrm{R}^{2}=0.0345323 \\
\text { Normality test: } \\
\text { Hetero test: } \\
\text { RESET test: }\end{array}$ & $\begin{array}{l}\mathrm{DW}=1.99 \\
\mathrm{Chi}^{2}(2)=71.618[* *] \\
\mathrm{F}(4,208)=0.71767 \\
\mathrm{~F}(1,212)=1.3028\end{array}$ \\
\hline BIOTON & $\begin{array}{l}0.0605 \\
(3.52)\end{array}$ & $\begin{array}{l}-0.1074 \gamma_{t} \\
(-2.09)\end{array}$ & $\begin{array}{r}+1.1218 \\
(2.37)\end{array}$ & & $\begin{array}{l}\mathrm{R}^{2}=0.0259491 \\
\text { Normality test: } \\
\text { Hetero test: } \\
\text { RESET test: }\end{array}$ & $\begin{array}{l}\mathrm{DW}=1.95 \\
\mathrm{Chi}^{2}(2)=144.13[* *] \\
\mathrm{F}(4,208)=0.73407 \\
\mathrm{~F}(1,212)=0.95979\end{array}$ \\
\hline BUDIMEX & $\begin{array}{r}0.0103 \\
(3.33)\end{array}$ & $\begin{array}{l}+0.1509\left|R_{t-1}\right| \\
\quad(2.23)\end{array}$ & $\begin{array}{r}+0.0027 \\
(0.715\end{array}$ & $9 \gamma_{t-1}$ & $\begin{array}{l}\mathrm{R}^{2}=0.0254123 \\
\text { Normality test: } \\
\text { Hetero test: } \\
\text { RESET test: }\end{array}$ & $\begin{array}{l}\mathrm{DW}=1.96 \\
\mathrm{Chi}^{2}(2)=121.13[* *] \\
\mathrm{F}(4,208)=0.37302 \\
\mathrm{~F}(1,212)=0.17456\end{array}$ \\
\hline $\mathrm{CCC}$ & $\begin{array}{l}0.0162 \\
(10.0)\end{array}$ & $\begin{array}{l}-0.00239 \gamma_{t} \\
(-0.9743)\end{array}$ & & & $\begin{array}{l}\mathrm{R}^{2}=0.00441564 \\
\text { Normality test: } \\
\text { Hetero test: } \\
\text { RESET test: }\end{array}$ & $\begin{array}{l}\mathrm{DW}=1.84 \\
\mathrm{Chi}^{2}(2)=61.986[* *] \\
\mathrm{F}(2,211)=0.017712 \\
\mathrm{~F}(1,213)=2.1941\end{array}$ \\
\hline $\mathrm{COL}$ & $\begin{array}{l}0.0159 \\
(5.21)\end{array}$ & $\begin{array}{l}+0.1384\left|R_{t-1}\right| \\
\quad(2.06)\end{array}$ & $\begin{array}{r}-0.0062 \\
(-1.37\end{array}$ & & $\begin{array}{l}\mathrm{R}^{2}=0.0293864 \\
\text { Normality test: } \\
\text { Hetero test: } \\
\text { RESET test: }\end{array}$ & $\begin{array}{l}\mathrm{DW}=1.97 \\
\mathrm{Chi}^{2}(2)=81.987[* *] \\
\mathrm{F}(4,208)=1.2986 \\
\mathrm{~F}(1,212)=3.3762\end{array}$ \\
\hline GANT & $\begin{array}{l}0.0539 \\
(4.25)\end{array}$ & $\begin{array}{l}-0.0098 \gamma_{t-1} \\
(-0.603)\end{array}$ & & & $\begin{array}{l}\mathrm{R}^{2}=0.0169782 \\
\text { Normality test: } \\
\text { Hetero test: } \\
\text { RESET test: }\end{array}$ & $\begin{array}{l}\mathrm{DW}=1.76 \\
\mathrm{Chi}^{2}(2)=258.02[* *] \\
\mathrm{F}(2,211)=0.79186 \\
\mathrm{~F}(1,213)=1.0534\end{array}$ \\
\hline IDM & $\begin{array}{l}0.0330 \\
(4.54)\end{array}$ & $\begin{array}{c}+0.0036 \gamma_{t} \\
(0.358)\end{array}$ & & & $\begin{array}{l}\mathrm{R}^{2}=0.000598048 \\
\text { Normality test: } \\
\text { Hetero test: } \\
\text { RESET test: }\end{array}$ & $\begin{array}{l}\mathrm{DW}=1.77 \\
\mathrm{Chi}^{2}(2)=26.764[* *] \\
\mathrm{F}(2,211)=1.7594 \\
\mathrm{~F}(1,213)=2.6924\end{array}$ \\
\hline KREZUS & $\begin{array}{l}0.0063 \\
(1.20)\end{array}$ & $\begin{array}{l}+0.465\left|R_{t-1}\right| \\
(7.73)\end{array}$ & $\begin{array}{c}+0.0227 \gamma_{t} \\
(2.07)\end{array}$ & $\begin{array}{l}-0.0224 \gamma_{t-1} \\
(-2.09)\end{array}$ & $\begin{array}{l}\mathrm{R}^{2}=0.233284 \\
\text { Normality test: } \\
\text { Hetero test: } \\
\text { RESET test: }\end{array}$ & $\begin{array}{l}\mathrm{DW}=1.97 \\
\mathrm{Chi}^{2}(2)=635.67\left[{ }^{* *}\right] \\
\mathrm{F}(6,206)=4.0813\left[{ }^{* *}\right] \\
\mathrm{F}(1,212)=5.2563[* *]\end{array}$ \\
\hline LCCORP & $\begin{array}{l}0.0158 \\
(3.71)\end{array}$ & $\begin{array}{l}+0.197\left|R_{t-1}\right| \\
(2.94)\end{array}$ & $\begin{array}{l}-0.00006 \gamma_{t-1} \\
(-0.0123)\end{array}$ & & $\begin{array}{l}\mathrm{R}^{2}=0.0390304 \\
\text { Normality test: } \\
\text { Hetero test: } \\
\text { RESET test: }\end{array}$ & $\begin{array}{l}\mathrm{DW}=1.98 \\
\mathrm{Chi}^{2}(2)=72.618\left[{ }^{* *}\right] \\
\mathrm{F}(4,208)=3.0924[*] \\
\mathrm{F}(1,212)=0.54384\end{array}$ \\
\hline CIA & $\begin{array}{l}0.0289 \\
(4.17)\end{array}$ & $\begin{array}{l}+0.139\left|R_{t-1}\right| \\
(2.06)\end{array}$ & $\begin{array}{l}-0.0168 \gamma_{t} \\
(-2.22)\end{array}$ & & $\begin{array}{l}\mathrm{R}^{2}=0.0469597 \\
\text { Normality test: } \\
\text { Hetero test: } \\
\text { RESET test: }\end{array}$ & $\begin{array}{l}\mathrm{DW}=2 \\
\mathrm{Chi}^{2}(2)=223.42\left[{ }^{* *}\right] \\
\mathrm{F}(4,208)=2.6867\left[{ }^{*}\right] \\
\mathrm{F}(1,212)=0.29551\end{array}$ \\
\hline
\end{tabular}

In brackets the t-Student statistics.

$*$ indicates significance at $5 \%, * *$ at $1 \%$.

Source: authors' own calculations. 
Table 4a. The best symptomatic models for $R^{2}$, and $D^{2}\left(u_{i}\right)$ as liquidity risk. Shares from WIG20.

\begin{tabular}{|c|c|c|c|c|c|c|}
\hline Shares & \multicolumn{4}{|c|}{ Equation for dependent variable } & \multicolumn{2}{|c|}{ Summary: regression and tests for residuals } \\
\hline BRE & $\begin{array}{l}0.00011 \\
(2.1)\end{array}$ & $\begin{array}{l}+0.304 R_{t-1}^{2} \\
(4.72)\end{array}$ & $\begin{array}{l}+1.3 D^{2}\left(u_{t}\right) \\
(3.18)\end{array}$ & $\begin{array}{l}-1.096 D^{2}\left(u_{t-1}\right) \\
(-2.68)\end{array}$ & $\begin{array}{l}\mathrm{R}^{2}=0.14574 \\
\text { Normality test: } \\
\text { Hetero test: } \\
\text { RESET test: }\end{array}$ & $\begin{array}{l}\mathrm{DW}=2.13 \\
\mathrm{Chi}^{2}(2)=249.78[* *] \\
\mathrm{F}(6,206)=2.0324 \\
\mathrm{~F}(1,212)=4.2130[*]\end{array}$ \\
\hline PEKAO & $\begin{array}{l}0.00019 \\
(3.97)\end{array}$ & $\begin{array}{l}+0.132 R_{t-1}^{2} \\
(1.96)\end{array}$ & $\begin{array}{l}+0.413 D^{2}\left(u_{t}\right) \\
(1.39)\end{array}$ & $\begin{array}{l}-0.503 D^{2}\left(u_{t-1}\right) \\
(-1.7)\end{array}$ & $\begin{array}{l}\mathrm{R}^{2}=0.0319863 \\
\text { Normality test: } \\
\text { Hetero test: } \\
\text { RESET test: }\end{array}$ & $\begin{array}{l}\mathrm{DW}=1.98 \\
\mathrm{Chi}^{2}(2)=2189.6[* *] \\
\mathrm{F}(6,206)=0.38709 \\
\mathrm{~F}(1,212)=0.0051429\end{array}$ \\
\hline HAWE & $\begin{array}{l}0.00048 \\
(2.492)\end{array}$ & $\begin{array}{l}+2.329 D^{2}\left(u_{t}\right) \\
(5.98)\end{array}$ & & $\begin{array}{l}1598 D^{2}\left(u_{t-1}\right) \\
5.2)\end{array}$ & $\begin{array}{l}\mathrm{R}^{2}=0.147086 \\
\text { Normality test: } \\
\text { Hetero test: } \\
\text { RESET test: }\end{array}$ & $\begin{array}{l}\mathrm{DW}=1.77 \\
\mathrm{Chi}^{2}(2)=630.91\left[{ }^{* *}\right] \\
\mathrm{F}(4,206)=5.6251[* *] \\
\mathrm{F}(1,212)=62.922[* *]\end{array}$ \\
\hline KGHM & $\begin{array}{l}0.00025 \\
(2.84)\end{array}$ & $\begin{array}{l}+0.4708 R^{2}{ }_{t-1} \\
\quad(7.77)\end{array}$ & & $\begin{array}{l}96 D^{2}\left(u_{t}\right) \\
63)\end{array}$ & $\begin{array}{l}\mathrm{R}^{2}=0.222643 \\
\text { Normality test: } \\
\text { Hetero test: } \\
\text { RESET test: }\end{array}$ & $\begin{array}{l}\mathrm{DW}=1.83 \\
\mathrm{Chi}^{2}(2)=367.27[* *] \\
\mathrm{F}(4,208)=14.605[* *] \\
\mathrm{F}(1,212)=0.0023946\end{array}$ \\
\hline LBW & $\begin{array}{r}0.00032 \\
(0.827)\end{array}$ & $\begin{array}{l}+3.482 D^{2}\left(u_{t}\right) \\
(6.14)\end{array}$ & & $\begin{array}{l}493 D^{2}\left(u_{t-1}\right) \\
5.2)\end{array}$ & $\begin{array}{l}\mathrm{R}^{2}=0.192377 \\
\text { Normality test: } \\
\text { Hetero test: } \\
\text { RESET test: }\end{array}$ & $\begin{array}{l}\mathrm{DW}=2.12 \\
\mathrm{Chi}^{2}(2)=1006.3[* *] \\
\mathrm{F}(4,206)=10.742[* *] \\
\mathrm{F}(1,212)=64.022[* *]\end{array}$ \\
\hline LPP & $\begin{array}{l}0.000246 \\
(2.82)\end{array}$ & $\begin{array}{l}+0.254 D^{2}\left(u_{t}\right) \\
(1.15)\end{array}$ & & & $\begin{array}{l}\mathrm{R}^{2}=0.00609248 \\
\text { Normality test: } \\
\text { Hetero test: } \\
\text { RESET test: }\end{array}$ & $\begin{array}{l}\mathrm{DW}=1.97 \\
\mathrm{Chi}^{2}(2)=707.43[* *] \\
\mathrm{F}(2,212)=0.20739 \\
\mathrm{~F}(1,212)=0.0026144\end{array}$ \\
\hline NETIA & $\begin{array}{l}0.00033 \\
(1.65)\end{array}$ & $\begin{array}{l}+5.825 D^{2}\left(u_{t}\right) \\
(9.17)\end{array}$ & & $\begin{array}{l}\text { 604 } D^{2}\left(u_{t-1}\right) \\
83)\end{array}$ & $\begin{array}{l}\mathrm{R}^{2}=0.28232 \\
\text { Normality test: } \\
\text { Hetero test: } \\
\text { RESET test: }\end{array}$ & $\begin{array}{l}\mathrm{DW}=1.9 \\
\mathrm{Chi}^{2}(2)=2120.3[* *] \\
\mathrm{F}(4,208)=11.105[* *] \\
\mathrm{F}(1,212)=156.38[* *]\end{array}$ \\
\hline PGNIG & $\begin{array}{l}0.00027 \\
(3.26)\end{array}$ & $\begin{array}{l}+2.025 D^{2}\left(u_{t}\right) \\
(5.57)\end{array}$ & & $\begin{array}{l}881 D^{2}\left(u_{t-1}\right) \\
19)\end{array}$ & $\begin{array}{l}\mathrm{R}^{2}=0.127447 \\
\text { Normality test: } \\
\text { Hetero test: } \\
\text { RESET test: }\end{array}$ & $\begin{array}{l}\mathrm{DW}=1.93 \\
\mathrm{Chi}^{2}(2)=894.07[* *] \\
\mathrm{F}(4,208)=6.8537[* *] \\
\mathrm{F}(1,212)=86.569[* *]\end{array}$ \\
\hline PKNORLEN & $\begin{array}{l}0.00038 \\
(4.21)\end{array}$ & $\begin{array}{l}+1.786 D^{2}\left(u_{t}\right. \\
(2.77)\end{array}$ & & $\begin{array}{l}.676 D^{2}\left(u_{t-1}\right) \\
2.61)\end{array}$ & $\begin{array}{l}\mathrm{R}^{2}=0.0347353 \\
\text { Normality test: } \\
\text { Hetero test: } \\
\text { RESET test: }\end{array}$ & $\begin{array}{l}\mathrm{DW}=1.7 \\
\mathrm{Chi}^{2}(2)=405.74[* *] \\
\mathrm{F}(4,208)=1.3336 \\
\mathrm{~F}(1,212)=3.7755\end{array}$ \\
\hline PKOBP & $\begin{array}{c}0.000117 \\
(4.47)\end{array}$ & $\begin{array}{c}+0.40778 D \\
\quad(2.97)\end{array}$ & $D^{2}\left(u_{t}\right)$ & & $\begin{array}{l}\mathrm{R}^{2}=0.039439 \\
\text { Normality test: } \\
\text { Hetero test: } \\
\text { RESET test: }\end{array}$ & $\begin{array}{l}\mathrm{DW}=2.08 \\
\mathrm{Chi}^{2}(2)=874.67[* *] \\
\mathrm{F}(2,212)=2.9235 \\
\mathrm{~F}(1,212)=1.4075\end{array}$ \\
\hline
\end{tabular}

In brackets the t-Student statistics.

$*$ indicates significance at $5 \%, * *$ at $1 \%$.

Source: authors' own calculations. 
Table $4 \mathrm{~b}$. The best symptomatic models for $R_{i}^{2}$, and $D^{2}\left(u_{i}\right)$ as liquidity risk. Shares from WIG80

\begin{tabular}{|c|c|c|c|c|c|c|}
\hline Shares & \multicolumn{4}{|c|}{ Equation for dependent variable } & \multicolumn{2}{|c|}{ Summary: regression and tests for residuals } \\
\hline AMICA & $\begin{array}{l}0.0002 \\
(3.27)\end{array}$ & $\begin{array}{l}+2.121 D^{2}\left(u_{t}\right) \\
(4.33)\end{array}$ & $\begin{array}{l}-2.0281 \\
(-4.14)\end{array}$ & & $\begin{array}{l}\mathrm{R}^{2}=0.0809859 \\
\text { Normality test: } \\
\text { Hetero test: } \\
\text { RESET test: }\end{array}$ & $\begin{array}{l}\mathrm{DW}=1.92 \\
\mathrm{Chi}^{2}(2)=469.76[* *] \\
\mathrm{F}(4,208)=13.132[* *] \\
\mathrm{F}(1,212)=35.188[* *]\end{array}$ \\
\hline BIOTON & $\begin{array}{l}0.00487 \\
(1.85)\end{array}$ & $\begin{array}{l}+1.021 D^{2}\left(u_{t-1}\right) \\
(4.19)\end{array}$ & & & $\begin{array}{l}\mathrm{R}^{2}=0.0754633 \\
\text { Normality test: } \\
\text { Hetero test: } \\
\text { RESET test: }\end{array}$ & $\begin{array}{l}\mathrm{DW}=2.02 \\
\mathrm{Chi}^{2}(2)=220.93[* *] \\
\mathrm{F}(2,210)=12.482[* *] \\
\mathrm{F}(1,212)=9.7776[* *]\end{array}$ \\
\hline BUDIMEX & $\begin{array}{c}0.0003169 \\
(3.23)\end{array}$ & $\begin{array}{l}+0.891 D^{2}\left(u_{t}\right) \\
(2.54)\end{array}$ & $\begin{array}{l}-0.7517 \\
(-2.15)\end{array}$ & & $\begin{array}{l}\mathrm{R}^{2}=0.029705 \\
\text { Normality test: } \\
\text { Hetero test: } \\
\text { RESET test: }\end{array}$ & $\begin{array}{l}\mathrm{DW}=1.76 \\
\mathrm{Chi}^{2}(2)=915.14[* *] \\
\mathrm{F}(4,208)=3.7046[* *] \\
\mathrm{F}(1,212)=16.648[* *]\end{array}$ \\
\hline $\mathrm{CCC}$ & $\begin{array}{l}0.00033 \\
(5.10)\end{array}$ & $\begin{array}{l}+0.0743 D^{2}\left(u_{t-1}\right. \\
(0.674)\end{array}$ & & & $\begin{array}{l}\mathrm{R}^{2}=0.00210887 \\
\text { Normality test: } \\
\text { Hetero test: } \\
\text { RESET test: }\end{array}$ & $\begin{array}{l}\mathrm{DW}=1.99 \\
\mathrm{Chi}^{2}(2)=1670.0[* *] \\
\mathrm{F}(2,210)=0.0074368 \\
\mathrm{~F}(1,212)=0.38909\end{array}$ \\
\hline $\mathrm{COL}$ & $\begin{array}{l}0.00036 \\
(4.66)\end{array}$ & $\begin{array}{l}+0.0594 D^{2}\left(u_{t-}\right. \\
(0.313)\end{array}$ & & & $\begin{array}{l}\mathrm{R}^{2}=0.000455558 \\
\text { Normality test: } \\
\text { Hetero test: } \\
\text { RESET test: }\end{array}$ & $\begin{array}{l}\mathrm{DW}=1.9 \\
\mathrm{Chi}^{2}(2)=375.23[* *] \\
\mathrm{F}(2,210)=1.1167 \\
\mathrm{~F}(1,212)=2.6412\end{array}$ \\
\hline GANT & $\begin{array}{l}0.0021 \\
(1.62)\end{array}$ & $\begin{array}{l}+1.074 D^{2}\left(u_{t}\right) \\
(3.50)\end{array}$ & $\begin{array}{l}-0.645 \\
(-2.10)\end{array}$ & & $\begin{array}{l}\mathrm{R}^{2}=0.0592479 \\
\text { Normality test: } \\
\text { Hetero test: } \\
\text { RESET test: }\end{array}$ & $\begin{array}{l}\mathrm{DW}=2.01 \\
\mathrm{Chi}^{2}(2)=1158.5[* *] \\
\mathrm{F}(4,208)=4.9348[* *] \\
\mathrm{F}(1,212)=0.11657\end{array}$ \\
\hline IDM & $\begin{array}{l}0.00242 \\
(5.84)\end{array}$ & $\begin{array}{l}+0.045 D^{2}\left(u_{t}\right) \\
(0.454)\end{array}$ & & & $\begin{array}{l}\mathrm{R}^{2}=0.0319863 \\
\text { Normality test: } \\
\text { Hetero test: } \\
\text { RESET test: }\end{array}$ & $\begin{array}{l}\mathrm{DW}=1.88 \\
\mathrm{Chi}^{2}(2)=285.47[* *] \\
\mathrm{F}(2,210)=1.0001 \\
\mathrm{~F}(1,212)=0.59442\end{array}$ \\
\hline KREZUS & $\begin{array}{c}-5.1 \mathrm{e}-005 \\
(-0.197)\end{array}$ & $\begin{array}{l}+0.329 R_{t-1}^{2} \\
\quad(5.11)\end{array}$ & $\begin{array}{r}+0.651 \\
\quad(2.43\end{array}$ & $2^{2}\left(u_{t}\right)$ & $\begin{array}{l}\mathrm{R}^{2}=0.155251 \\
\text { Normality test: } \\
\text { Hetero test: } \\
\text { RESET test: }\end{array}$ & $\begin{array}{l}\mathrm{DW}=1.82 \\
\mathrm{Chi}^{2}(2)=18,328 .[* *] \\
\mathrm{F}(4,208)=3.4786\left[{ }^{* *}\right] \\
\mathrm{F}(1,212)=1.5503\end{array}$ \\
\hline LCCORP & $\begin{array}{c}0.00074 \\
(3.93)\end{array}$ & $\begin{array}{l}+0.197 R_{t-1}^{2} \\
(3.02)\end{array}$ & $\begin{array}{l}+0.976 D^{2}\left(u_{t}\right) \\
(2.82)\end{array}$ & $\begin{array}{l}-1.124 D^{2}\left(u_{t-1}\right) \\
(-3.24)\end{array}$ & $\begin{array}{l}\mathrm{R}^{2}=0.0910506 \\
\text { Normality test: } \\
\text { Hetero test: } \\
\text { RESET test: }\end{array}$ & $\begin{array}{l}\mathrm{DW}=2 \\
\mathrm{Chi}^{2}(2)=507.44[* *] \\
\mathrm{F}(6,206)=1.7375 \\
\mathrm{~F}(1,212)=9.2332[* *]\end{array}$ \\
\hline CIA & $\begin{array}{c}0.00086 \\
(2.80)\end{array}$ & $\begin{array}{l}+2.0525 D^{2}\left(u_{t}\right) \\
\quad(3.74)\end{array}$ & $\begin{array}{l}-2.263 \\
(-4.11)\end{array}$ & $\left.t_{t-1}\right)$ & $\begin{array}{l}\mathrm{R}^{2}=0.0731037 \\
\text { Normality test: } \\
\text { Hetero test: } \\
\text { RESET test: }\end{array}$ & $\begin{array}{l}\mathrm{DW}=1.88 \\
\mathrm{Chi}^{2}(2)=2693.2\left[{ }^{*}\right] \\
\mathrm{F}(6,206)=12.413[* *] \\
\mathrm{F}(1,212)=37.947[* *]\end{array}$ \\
\hline
\end{tabular}

In brackets the t-Student statistics.

$*$ indicates significance at $5 \%, * *$ at $1 \%$.

Source: authors' own calculations. 


\section{References}

Amihud, Y. (2002). Illiquidity and stock returns: cross-section and time-series effects. Journal of Financial Markets, 5: 31-56.

Amihud, Y. \& Mendelson, H. (1986). Asset pricing and the bid-ask spread. Journal of Financial Economics, 17: 223-249.

Avramov, D., Chordia, T. \& Goyal, A. (2006). Liquidity and Autocorrelation in Individual Stock Returns, Journal of Finance, 61 (5): 2365-2394.

Battesse, G.E. \& Coelli, T.J. (1992). Frontier production functions, technical efficiency and panel data with application to paddy fanners in India. Journal of Productivity Analysis, 3: 153-169.

Battesse, G.E. \& Coelli, T.J. (1995). A Model for Technical Inefficiency Effects in a Stochastic Frontier Production Function for Panel Data. Empirical Economics, 20: $325-332$.

Battesse, G.E. \& CoRRA, G.S. (1977). Estimation of a Production Frontier Model: Witch Application to the Pastoral Zone of Eastern Australia. Australian Journal of Agricultural Economics, 21: 169-179.

Engle, R.F. (1982). Autoregressive conditional heteroscedasticity, with estimates of the variance of United Kingdom inflation. Econometrica, 50: 987-1007.

Garsztka P. (2012). Konstrukcja portfela papierów wartościowych z uwzględnieniem płynności walorów. In: Matematyka i informatyka na ustugach ekonomii : metody, analizy, prognozy. Ed. D. Appenzeller. Poznań: Wydawnictwo Uniwersytetu Ekonomicznego w Poznaniu (UEP), No. 242 (pp. 56-68).

Harvey, A.C. (1990). The Econometric Analysis of Time Series. 2nd ed. Hemel Hempstead: Philip Allan.

Jacobs, B. \& Levy, K. (2013). Leverage Aversion, Efficient Frontiers, and the Efficient Region. The Journal of Portfolio Management, 39 (3): 54-64.

Markowitz, H. (1952). Portfolio selection. Journal of Finance, 7: 77-91.

Pastor, L. \& Stambaught, R. (2003). Liquidity risk and expected stock returns. Journal of Political Economy. 111: 642-685.

Pla-Santamaria, D. \& Bravo, M. (2013). Portfolio optimization based on downside risk: a meansemivariance efficient frontier from Dow Jones blue chips. Annals of Operations Research, 205 (1): 189-201.

Sharpe, W.F. (1970). Portfolio Theory and Capital Markets. McGraw-Hill, USA.

Wolski, R. (2013). Measures of downside risk under conditions of downturn in the real estate market. Real Estate Management and Valuation, 21 (3): 81-87. 